\title{
Corporate Social Responsibility Practices in Bangladesh: A Statistical Analysis on State-Owned \& Private Commercial Banks
}

\author{
Ishita Roy, Amit Kumar Sarker \\ Bangabandhu Sheikh Mujibur Rahman Science \& Technology University, Gopalganj, Bangladesh \\ Swapna Chowdhury \\ University of Development Alternative, Dhaka, Bangladesh
}

\begin{abstract}
Corporate Social Responsibility (CSR) is integral and inseparable part of the long term business and sustainable growth and success, which plays an important role in promoting values both locally and internationally and usually is noticed as a developed-country sensation. As such, a great figure of literature on social arrangement of organizations has appeared in the perspective of developed states. CSR is an assurance of the organizations to action morally and add to financial progress of the people while improving the worth of the life of the employees and the local public in general. All over the world, CSR is essential for the organizations to confirm its sustainability. Though, CSR is a worldwide issue and all organizations practice it to some degree. In this paper, the authors made a determination to explain CSR and the related matter, and scrutinize the well-being performances of some State-Owned Commercial and Private Commercial Banks in Bangladesh. As the central bank of Bangladesh, "Bangladesh Bank" has advised the commercial banks to play an effective part in the well-being of people. Therefore, this paper is an attempt to discover the degree to which the mentioned banks in Bangladesh accomplish their CSR activities and to search the level of revelation for CSR in their annual reports. The research has been directed with secondary data collected from the annual reports of the mentioned banks of more than a few years. Against this backdrop, this paper debates the situation prevailing practices of CSR in mentioned banks. The paper presented here in the three fold continuingly reviews the literature concerning CSR in the context of the contemporary world; inspects the well-being practices and presents the data of CSR practices of the mentioned banks and lastly presents the limitations and recommendations for better CSR practices of the mentioned banks in Bangladesh.
\end{abstract}

Keywords: CSR, Private Commercial Banks (PCBs), State-Owned Commercial Banks (SoCBs), welfare, Bangladesh

Ishita Roy, assistant professor, Department of Management Studies, Bangabandhu Sheikh Mujibur Rahman Science \& Technology University, Gopalganj, Bangladesh.

Amit Kumar Sarker, MBA, Department of Management Studies, Bangabandhu Sheikh Mujibur Rahman Science \& Technology University, Gopalganj, Bangladesh.

Swapna Chowdhury, assistant professor, Department of BBA, University of Development Alternative, Dhaka, Bangladesh.

Correspondence concerning this article should be addressed to Swapna Chowdhury, Department of BBA, University of Development Alternative, Dhaka, Bangladesh. 


\section{Introduction}

In modern times, corporate social responsibility (CSR) has created a remarkable discussion in academic and corporate arenas. This discussion admits the significance of CSR in the first world, but raises questions about the degree to which organizations functioning in developing countries have CSR commitments. Conventional knowledge suggests that CSR is more pertinent to companies working in the developed countries owing to higher public expectations of communally responsible behavior. In contrast, similarly there is a faith that social expectations in the developing countries mostly centered on financial progress; thus referring CSR to be of minor prominence to the people and the organizations (Quazi, Rahman, \& Keating, 2007). CSR is comparatively a new thought in Bangladesh and all the organizations attempt to retain this responsibility together with other responsibilities. The banking sector in Bangladesh has a wonderful history of getting involved themselves in diverse kinds of social events which are properly known as CSR like assistances to diverse groups, state beautification, patronizing cultural events, etc. However, in current years, there is fabulous progress in this envelopment, since in 2008, Bangladesh Bank Guideline advised the banks to involve in these events in a more organized way (Mahbuba \& Farzana, 2013).

The determination of business is to create the opportunity to earn money. Though, the profit purpose is sometimes observed as less than moral as it stresses self-interest. Yet, self-interest is not the equal as selfishness, which stresses one's personal wellbeing at others' expenditure. Self-interest is only a concern for monetary return and is essential if society is to be greatly productive and competently deal its assets (Safety \& Rights Society, 2014). Profit rewards hard work and invention, inducements that most individuals want because otherwise it would be unreasonable to save and invest rather than consume. Therefore, business organizations cannot work effectively without the assistance of the society in which it is situated. Businesses should adopt social responsibilities as they are amongst the few private bodies that have the assets to do this. The business world has certain of the liveliest thinkers in the world and it holds wonderful economic funds (Ahmed, 2012). Therefore, businesses should develop some of their social and economic capital so as to "create the world a good place."

\section{Definition of CSR}

CSR is one of business's responsibilities to its stakeholder and also a deliberate involvement by corporation to viable advancement (Crane \& Matten, 2007). In the period of growing corporate financial gossips, CSR has come to being a significant policy for corporations worldwide to develop their images as these events can possibly generate a brand image for corporations and improve good relationships with stakeholders. Carrol (1991) defined corporate social responsibility (CSR) as "an organization's commitment to operate in an economically and environmentally sustainable manner while recognizing the interests of all its stakeholders”. The European Union's (EU) Green Paper Promoting a European Framework for Corporate Social Responsibility (2001) defined CSR as "a concept whereby companies integrate social and environmental concerns in their business operations and in their interaction with their stakeholders on a voluntary basis." CSR can be observed as an all-inclusive set of strategies, observations, and programs that are combined with corporate actions, resource chains, and assessment making procedures through the corporation and comprise duties for present and past activities along with sufficient devotion to future effects. CSR's efforts differ by segment, by size, and by business even by geographical area. The concept of CSR is fairly vast and it contains all the moral performances that rise the corporate productivity and can serve the interest of all stakeholders. 


\section{Literature Review}

There is a long history in Bangladesh of generous deeds from ancient time. These charitable events incorporated aids to diverse poor people, charitable societies, and religious organizations (Alimullah, 2006). Common CSR practices in Bangladesh by different Organization are centered on mainly poverty alleviation, healthcare, education, charity activates, cultural enrichment, youth development, women empowerment, patronizing sports and music, etc.

Researchers conducted a survey among 10 commercial banks and found that 100 banks reported their CSR activities but $60 \%$ of banks participated in prescribed CSR area according to financial act. CSR reporting is growing gradually in other zones like Asia, Europe, Latin America, and North America.

Azim, Ahmed, and D’Netto (2011) revealed corporate social responsibility is not simply moral dilemma that economic organizations face in an atmosphere of immoral corporate exercise. These organizations are as well concerned with the assurance of sustainable progress. A sound-working finance segment in any state can donate directly to a healthy economy. Besides mentioning, that CSR recording of monetary sector in Bangladesh is growing and society is worried about the issue and considerably preserved in the annual report.

In a study named CSR Practices and CSR Reporting in Indian banking sector mentioned CSR recognizes an organization's commitment to operating in a socially responsible manner. But CSR activities of developing nations are not so rosy. Particularly in financial sector there is an absence of stringent provisions regarding compliances and reporting CSR.

In a theoretical paper; "Banking Reputation and CSR: A Stakeholder Value Approach” pointed out that, CSR is a significant reputation driver, capable to make economic value over a period. The authors identify in their study that there is a connection between CSR and business status.

Alam et al. (2010) revealed that CSR is still a progressing idea that assists business executives to make and put on self-resoluted strategies to greatest encounter the requirements and needs of its stakeholders. Now, it has observed that the peculiar nature of carrying out CSR creates their cross-border managing tough. Attaining constant CSR performances through global operations includes not only the transference of the CSR exercise, but also the transference of its essential value and significance.

World Bank (2020) pronounced CSR as the businesses' responsibilities to deliver renewable financial growth through teamwork with personnel, their families, the local public, and the humanity in a way that improves their livelihood and accordingly leads to favorable trade and expansion.

Nowadays, the Corporate Social Responsibility is a worldwide concern. However, it is a matter of regret that it still is witnessed widely international arena, but in Bangladesh, it is lagging behind relating to developed states of the world. Sustainable growth is not possible without the assistance of the business world.

\section{Objectives of the Study}

The aims of this paper are to understand the CSR practices of four State-Owned Commercial Banks (SoCBs) and as well as four selected Private Commercial Banks (PCBs) in Bangladesh. There are several particular objectives which are also given below:

- to study the concept of CSR;

- to study the major areas of CSR initiatives of SoCBs in Bangladesh;

- to focus on the present status of CSR in SoCBs; 
- to evaluate and inspect the role of CSR activities of SoCBs in Bangladesh;

- to know the CSR area of Selected Banks where they perform CSR.

\section{Methodology}

Secondary data were the principal base of information for the study. Bangladesh Bank's publications, Banks' websites, periodicals, and newspapers are utilized as the secondary sources of the study. A number of books and related articles from several journals are also utilized to improve the basic knowledge about the specific matter and numerous international determinations and creativities for increasing and executing CSR principles and guidelines were inspected.

\section{Finding and Analyses}

\section{CSR Practices of State-Owned Private Commercial Banks in Bangladesh}

The main concern of this paper is to ascertain the participation of SoCBs of Bangladesh in CSR events. For this, in this paper, focus has been drawn only upon the CSR of four full-fledged SoCBs in Bangladesh. The list of these four banks is given below in Table 1 .

Table 1

CSR Contributions of State-Owned Commercial Banks in Bangladesh: Highlights 2014-2015 Annual Basis

\begin{tabular}{|l|l|}
\hline SL & State-Owned Commercial Banks (SoCBs) \\
\hline 1 & Sonali Bank Limited (SBL) \\
\hline 2 & Janata Bank Limited (JBL) \\
\hline 3 & Agrani Bank Limited (ABL) \\
\hline 4 & Rupali Bank Limited (RBL) \\
\hline
\end{tabular}

Background of SoCBs in Bangladesh. Sonali Bank Limited (SBL) is a state-owned top commercial bank in Bangladesh. It is the prime bank of the state. Under the Bangladesh Banks (Nationalization) Order, it was established in 1972, through the incorporation and nationalization of the branches of National Bank of Pakistan, Bank of Bhowalpur, and Premier Bank branches situated in East Pakistan till the 1971 Bangladesh Liberation War. The bank operates the Project Finance, SME Finance, Corporate Banking, International Trade, Trade Finance, International Trade, Trade Finance, Consumer Credit, Loan Syndication, Foreign Exchange Dealing, Rural and Micro credit, NGO-Linkage Loan, Investment, Money Market Operation, Government Treasury Function, Remittance services, and Capital Market Operation (Sonali Bank Limited, n.d.).

Janata Bank Limited (JBL). JBL is a state owned commercial bank established in 1971 and is providing the necessity of the mass corporate publics. Its head office is located at Motijheel in Dhaka-the capital city of Bangladesh. It is known as the second leading commercial bank in Bangladesh (Janata Bank Limited, n.d.). It was corporatized on 15th November 2007. The bank was born with a fresh idea of decisive banking sub serving the growing and diversified financial needs of planned economic development of the country (Janata Bank Limited, n. d).

Agrani Bank Limited (ABL). ABL is a nationalized commercial bank (NCB) of Bangladesh established under the Bangladesh Banks (Nationalization) Order 1972 by taking over two abandoned Pakistani banks Habib Bank and Commerce Bank on March 26, 1972. The bank has been transformed into a Public Limited Company with 100\% possession of the government and started working from November 15, 2007 as Agrani Bank Limited (ABL) through taking over all assets, liabilities, and business of Agrani Bank on the source of 
Vendors Agreement sign up between the Government and the Agrani Bank. After corporatization, the administration of the bank has been set autonomy to create the bank viable and to run its commercial activities efficiently (Islam, 2014).

Rupali Bank Limited (RBL). RBL is another commercial bank in Bangladesh. It was established on March 26, 1972 under the Bangladesh Banks (Nationalization) Order 1972 (P.O. No. 26 of 1972) with the amalgamation of three former commercial banks, namely Australasia Bank Ltd., Muslim Commercial Bank Ltd., and Standard Bank Ltd. functioned in the then Pakistan, by means of all their benefits, assets, powers, rights, authorities, privileges, borrowings liabilities, and obligations. Till December 13, 1986, Rupali Bank functioned as a nationalized commercial bank. RBL appeared as the biggest Public Limited Banking Company of the state on December 14, 1986 (Rupali Bank Limited, n.d.).

Table 2

Year Wise Banks’ Disbursement

\begin{tabular}{llll}
\hline Name & 2012 & 2013 & 2014 \\
\hline Sonali Bank Limited (SBL) & 2.63 & 4.91 & 4.52 \\
Janata Bank Limited (JBL) & 13.76 & 42.68 & 13.84 \\
Agrani Bank Limited (ABL) & 10.41 & 0.72 & 6.47 \\
Rupali Bank Limited (RBL) & 0.37 & 5.24 & 2.33 \\
Total & 27.17 & 53.55 & 27.16 \\
\hline
\end{tabular}

Source: Bangladesh Bank.

Table 2 depicts that, from 2012-2014, the disbursement of SBL is 2.63, 4.91, and 4.52 crore taka consecutively. JBL disbursed from 2011-2014 consecutively 13.76, 42.68, and 13.84 crore taka. ABL disbursed from 2012-2014 consecutively 10.41, 0.72, and 6.47 crore taka. The last one of the table RBL from 2012-2014 disbursed $0.37,5.24$, and 2.33 crore taka consecutively.

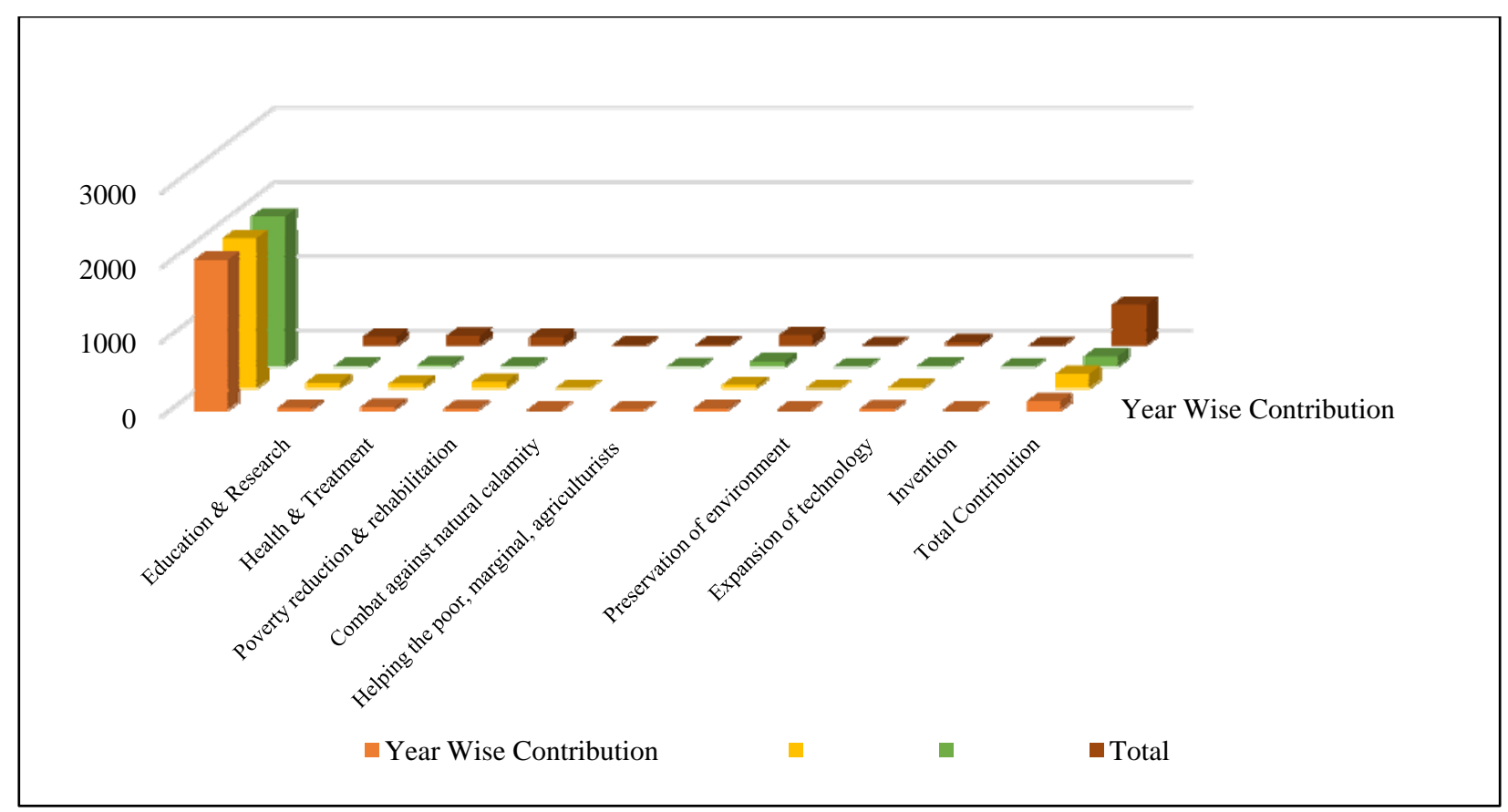

Figure 1. Year wise contribution. Source: Compilation of annual report of SBL. 
SBL as the principal SoCBs in the state has been playing a significant role in executing societal and charitable programmes to support deprived people of the state. The CSR events of SBL continue to increase thrust and produce honors from diverse segments in Bangladesh (SBL, 2016). Figure 1 depicts that in the education sector from 2012-2015, the total disbursement is 51.6 million taka. The disbursement from 2012-2015 in healthcare, humanitarian, and disaster management and self-employment sector are 13.4, 52.6, and 0.2 million consecutively. In environment, arts, and culture and liberation war related disbursement from 2012-2015 are 0.3, 0.3, and 1.4 million taka consecutively. The disbursement from 2012-2015 in publication sector is 0.1 and miscellaneous sector is 0.8 million taka. From the years 2012-2015, the total disbursements of different segments of CSR are 26.4, 49.1, and 45.2 million taka respectively.

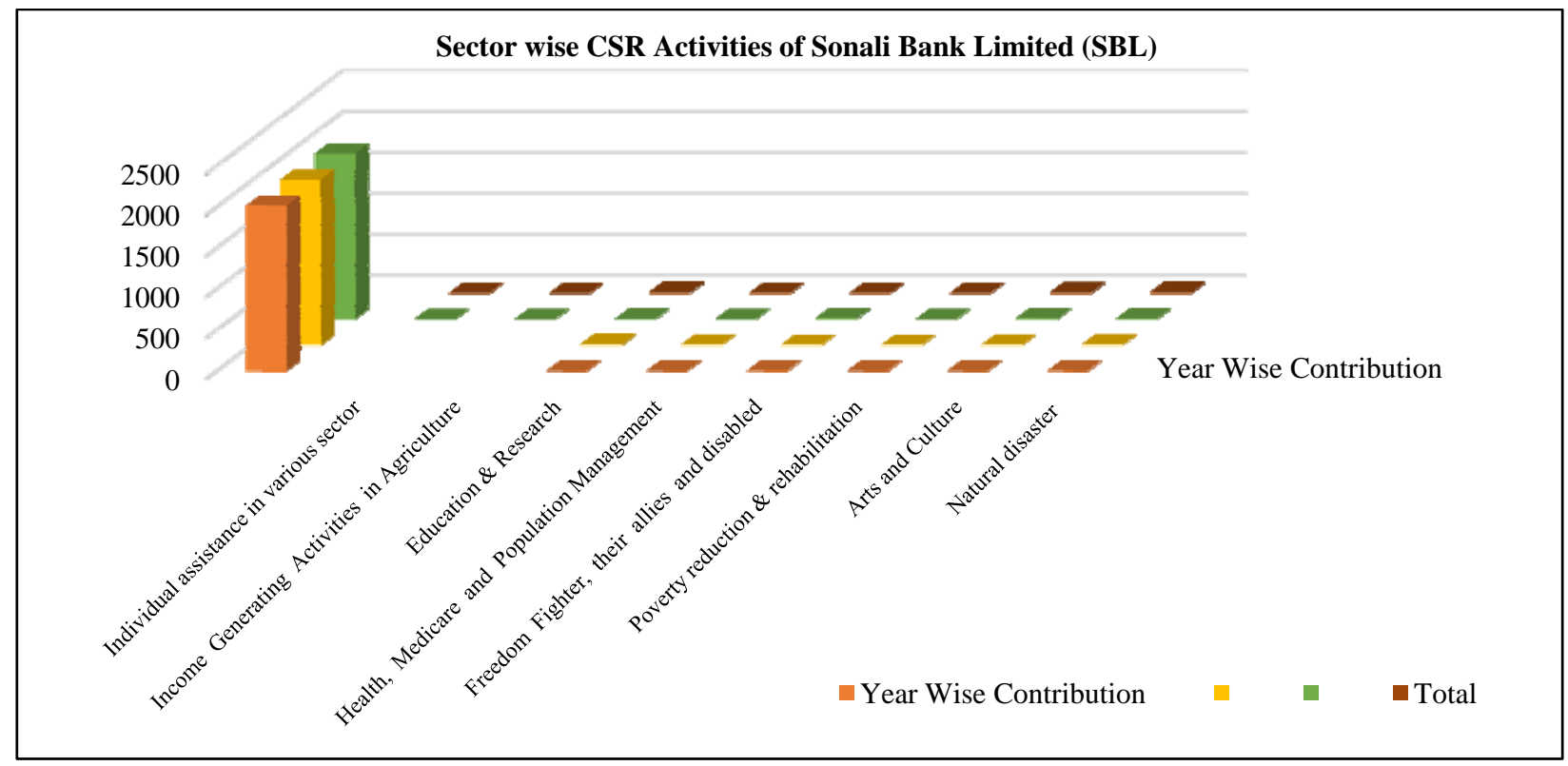

Figure 2. Year wise contribution. Source: Compilation of annual report of JBL.

As an SoCB, JBL has concerned to increase of maintainable business outcome viz and to gain profit, environmental safety, and maintenance and development of the lifestyle of the individuals of the society. JBL trusts that CSR is around how corporations maintain the business procedures to create an inclusive, positive effect on society (JBL, 2014). JBL provides financial support under its various CSR events. Figure 2 depicts that in education and research sector from 2012-2015, the total disbursement is 114.34 million Taka. The disbursement from 2012-2015 in health and treatment, poverty reduction, and rehabilitation and combat against natural calamity are 124.96, 111.58, and 4.5 million consecutively. In helping the poor, marginal, agriculturists sector, preservation of history-tradition, culture, and sports sector and preservation of environment disbursement from 2012-2015 are 10.0, 135.75, and 1.05 million taka consecutively. The disbursement from 2012-2015 in expansion of technology is 40.41 and invention sector is 0.70 million taka. The total disbursement from 2012-2015 in various sectors is 543.29 million taka.

ABL is dedicated to donating to societal progress through its CSR activities. The ABL's moral standard is not only intended for increasing profit, but also its prophecy is to form a society where human respect and rights obtain the maximum attention and assessment. The Bank's slogan is as well to progress the society and its values by means of CSR (ABL, 2016). Figure 3 depicts that in education, health, care, and disaster relief, the 
disbursement from 2012-2015 is consecutively 52.89, 27.66, and 42.75 million taka. The disbursement from 2012-2015 in the environment, sports, arts, culture and other sectors is 16.8, 21.77, 12.68, and 27.19 consecutively. The total contribution of ABL in various sectors from 2012-2015 is 201.74 million taka.

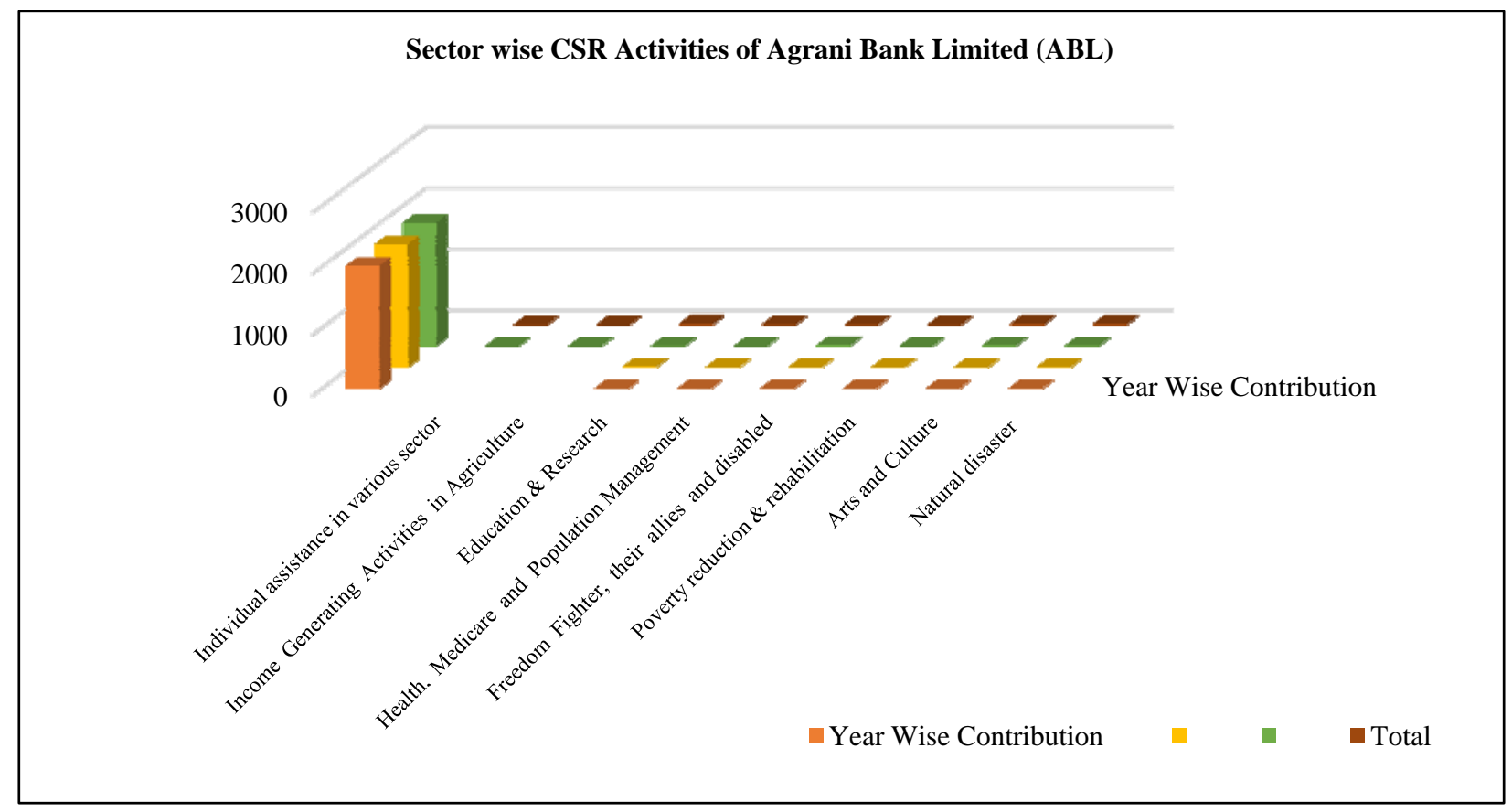

Figure 3. Year wise contribution. Source: Compilation of annual report of ABL.

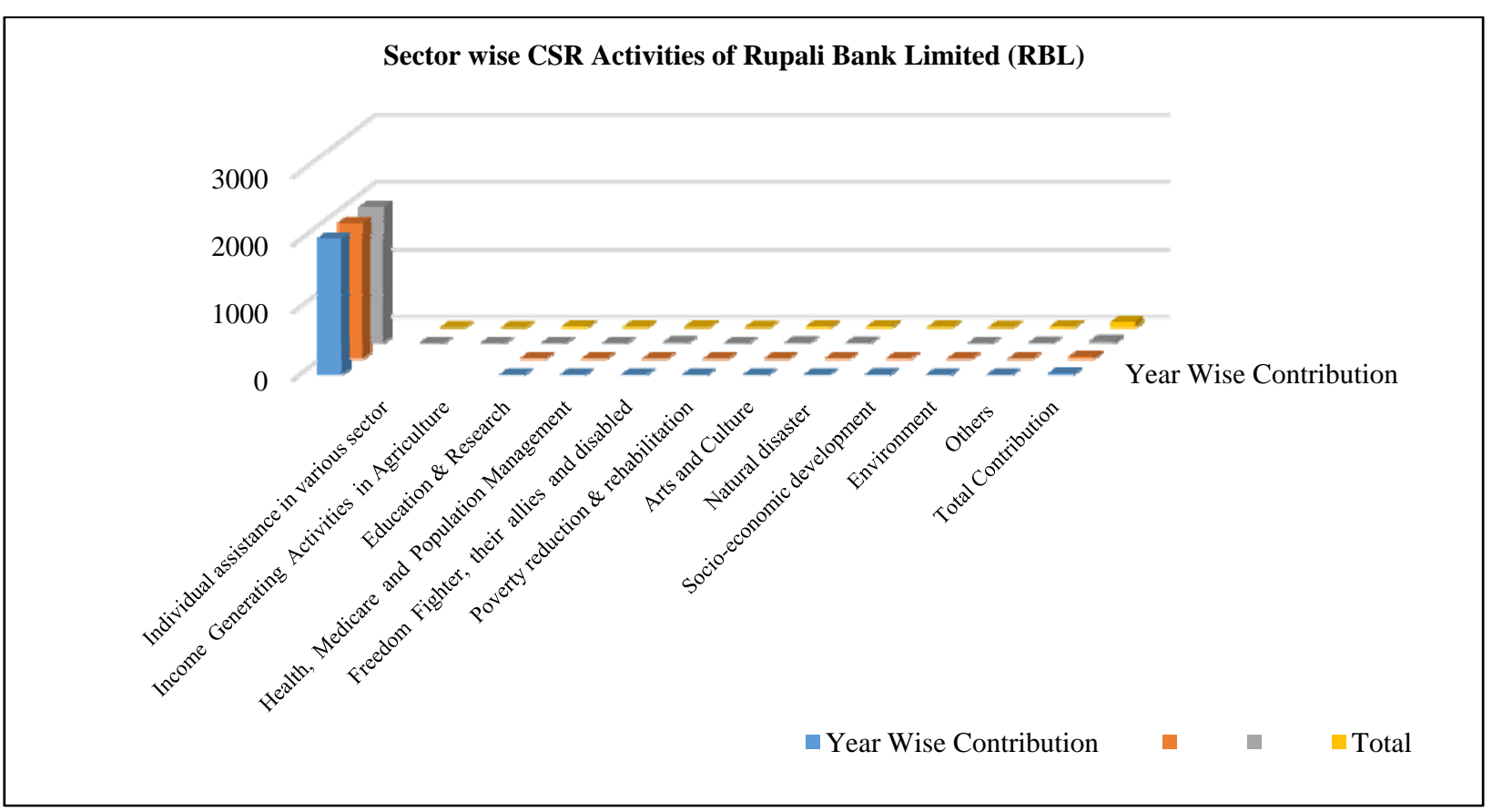

Figure 4. Year wise contribution. Source: Compilation of annual report of RBL.

CSR activities of RBL actually intended at answering the enormous unmet request of the people. It inclines to corporate activities more devoted to social requirements and national needs through legitimate and 
viable manner (RBL, 2014). Figure 4 reveals that individual assistance in various sectors is 1.40 million taka from 2012-2014. The disbursement from 2012-2014 in income generating activities in agriculture, education, research, and health, medicare and population management sectors is consecutively 10, 16.74, and 5.95 million taka. In freedom fighter, their allies and disabled, poverty reduction, rehabilitation, arts, culture, and natural disaster are 4.47, 2.76, 13.77 and 15.52 million taka consecutively from 2012-2015. The disbursement in socio-economic development, environment and others sector is 7.35, 2.5, and 7.89 million taka from 2012-2014 consecutively. The total disbursement of CSR in 2012 is 15.29 million taka, 32.18 million taka in 2013, and total disbursement in 2015 is 30.78 million taka.

\section{CSR Practices of Private Commercial Banks in Bangladesh}

The main concern of this paper is to ascertain the participation of PCBs of Bangladesh in CSR events. For this, in this paper, focus has been drawn only upon the CSR of four full-fledged PCBs in Bangladesh. The list of these four banks is given below in Table 3.

Table 3

List of PCBs

\begin{tabular}{ll}
\hline SL & Private Commercial Banks (PCBs) \\
\hline 1 & BRAC Bank Ltd \\
2 & The City Bank Ltd \\
3 & Standard Bank Ltd \\
4 & Southeast Bank Ltd \\
\hline
\end{tabular}

The research method of the study involved examination, verifying, and analysis of the annual reports of selected Private Commercial Banks (PCB) to observe the practices of CSR reporting in touch the above research objectives. Content analysis has been widely used for CSR studies and the study has also taken an attempt to observe CSR reporting of PCBs by using content analysis. The study has divided different CSR activities of PCBs into five major areas: (a) education, (b) health, (c) environment and disaster, (d) culture and sport, and (e) miscellaneous. The above five major areas have been used to show PCBs CSR practices with the prevailing finance act 2015. The study has taken an attempt to verify with the finance act 2015, prescribed several areas of CSR expenditures with four PCBs annual report CSR disclosures.

Table 4

CSR Contributions of Commercial Banks in Different Areas: Highlights 2014-2015 Annual Basis

\begin{tabular}{|l|l|l|}
\hline SL & CSR area & Contribution of Brac Bank Ltd \\
\hline 1 & Education & $\begin{array}{l}393 \text { students have got help to pursue higher study. 1,700 students got recognition for their } \\
\text { worthy result. 2,000 students got inspired for higher study and research in science. 10 students } \\
\text { can continue their higher study. }\end{array}$ \\
\hline 2 & Environment & $\begin{array}{l}1000 \text { people including } 700 \text { students promised to protect the environment. } 250 \text { children were } \\
\text { given saplings and got to become about the importance of environment. }\end{array}$ \\
\hline 3 & Young leadership & $\begin{array}{l}16 \text { universities took part in the first ever university level women's debate competition in the } \\
\text { country. }\end{array}$ \\
\hline 4 & Social welfare & $\begin{array}{l}2,000 \text { employees ran for humanity. 26,500 cold-hit people have received clothes to survive } \\
\text { winter nights. Road Accident Memorial has been built in Dhaka University premises to raise } \\
\text { public awareness about road safety issues. }\end{array}$ \\
\hline 5 & Art \& culture & $\begin{array}{l}\text { More than 55,000 people have found roots in classical music. Countless readers will get access } \\
\text { to online reading. }\end{array}$ \\
\hline 6 & Health & 446 hearing impaired children will get better diagnosis. 50 nursing students got residential facility. \\
\hline
\end{tabular}




\begin{tabular}{|c|c|c|}
\hline SL & CSR area & Contribution of The City Bank Ltd \\
\hline 1 & Education & $\begin{array}{l}\text { Donate Laptop and Other Accessories to Visually Impaired Person: Ms. Jarina Akhter, a } \\
\text { resident of Ghorashal, Narshingdi district is a visually impaired person. Despite her disabilities, } \\
\text { she has completed Bachelors and Masters of Social Science from Dhaka Universityand also had } \\
\text { taken a few courses in using computer. But as she is not financially well off, she cannot afford } \\
\text { to buy a computer and continue her studies any further. }\end{array}$ \\
\hline 2 & Donation & $\begin{array}{l}\text { City Bank is always committed to supporting students who are the future of the society and the } \\
\text { country. Considering the learning opportunities of the students, City Bank provided a donation } \\
\text { of BDT 375,000 to the Department of Development studies in order to bare the lion share of the } \\
\text { expenses of the study tour. }\end{array}$ \\
\hline 3 & Training \& development & $\begin{array}{l}\text { City Bank donated BDT 4,460,000 to IBB. Because the Institute of Bankers, Bangladesh (IBB) } \\
\text { is a professional body of banks and financial institutions in Bangladesh. The basic objective of } \\
\text { this institute is to develop professionally qualified and competent bankers primarily through a } \\
\text { process of training, examination, and continuing professional development programs. }\end{array}$ \\
\hline 4 & Social welfare & $\begin{array}{l}\text { Winter Cloth Distribution: In 2014, like every year, City Bank has distributed blankets among } \\
\text { the poor through its } 102 \text { branches countrywide to ensure that the help reaches to all those who } \\
\text { need it. At the same time, City Bank collaborated with Prothom Alo Trust and donated blankets } \\
\text { to their pool of winter clothes to be distributed among the poor. } \\
\text { City Bank, as part of its responsibility towards the society has been providing financial support } \\
\text { to the martyrs of tragic } 2009 \text { BDR Mutiny. Form the very year, the bank is contributing BDT } \\
40,000 \text { per month for up to ten years to the family of BDR martyr Major Mohammad Mosharr } \\
\text { of Hossain. In 2014, the bank issued a pay order of BDT } 480,000 \text { to Ms. Kamrun Nahar Lipi, } \\
\text { Wife of the martyred officer as help for the whole year of 2013. }\end{array}$ \\
\hline SL & CSR area & Contribution of Standard Bank Ltd \\
\hline 1 & Education & $\begin{array}{l}\text { The bank helps the poor and meritorious student to discover their own potential in the area of } \\
\text { academic development. Recognizing “education” as a focus area of the bank's CSR activities. } \\
\text { The Bank has expensed BDT } 3.09 \text { million for Education Sector during the year } 2014 \text { in direct } \\
\text { social intervention and supplementing initiatives to the community. }\end{array}$ \\
\hline 2 & $\begin{array}{l}\text { Health care, social } \\
\text { awareness, rehabilitation } \\
\text { program, natural disaster }\end{array}$ & $\begin{array}{l}\text { During the year 2014, BDT } 48.30 \text { million was contributed for social and philanthropic causes } \\
\text { under CSR activities of the Bank in the form of Direct Social Intervention and Community } \\
\text { Development Project. }\end{array}$ \\
\hline 3 & Young leadership & $\begin{array}{l}\text { Sixteen universities took part in the first ever university level women's debate competition in } \\
\text { the country. }\end{array}$ \\
\hline 4 & Social welfare & $\begin{array}{l}\text { 2,000 employees ran for humanity. 26,500 cold-hit people have received clothes to survive } \\
\text { winter nights. Road Accident Memorial has been built in Dhaka University premises to raise } \\
\text { public awareness about road safety issues. }\end{array}$ \\
\hline 5 & Art \& culture & $\begin{array}{l}\text { More than 55,000 people have found roots in classical music. Countless readers will get access } \\
\text { to online reading. }\end{array}$ \\
\hline 6 & Health & 446 hearing impaired children will get better diagnosis. Fifty nursing students got residential facility. \\
\hline SL & CSR area & Contribution of Southeast Bank Ltd \\
\hline 1 & Education & $\begin{array}{l}\text { Keeping backbone of nation view of mind, Southeast Bank Foundation has been working } \\
\text { consistently from 2009. The main aim of this scholarship program is giving scholarship at the } \\
\text { meritorious students who are coming from low incomes families. }\end{array}$ \\
\hline 2 & Green school project & $\begin{array}{l}\text { SEBF is developing a green school. Keeping the small children in mind and aiming to create an } \\
\text { environment conductive to their comfortable learning SEBF has adopted policies, strategies, } \\
\text { curricula, and the school facilities after thorough research and careful consideration. }\end{array}$ \\
\hline 3 & Health sector & $\begin{array}{l}\text { Health is the most important strictures to achieve Millennium Development Goal (MDG). } \\
\text { Southeast Bank donated BDT } 3.37 \text { million to different disadvantage people for medical treatment. }\end{array}$ \\
\hline 4 & Environment & $\begin{array}{l}\text { The beautification of the road-island from Russell Square to Manik Miah Avenue was done by } \\
\text { the bank. Southeast bank donated BDT 100,000 to Bangladesh BannyaPrani Sheba Foundation } \\
\text { for the development of BannyaPrani life style. }\end{array}$ \\
\hline 5 & Community development & $\begin{array}{l}\text { Seven selected bereaved families of the Shaheed (Martyr) Army Officers is being given BDT } \\
40,000.00 \text { only per month and BDT } 480,000.00 \text { per yearly totally BDT } 3,360,00.00 \text { donated and } \\
\text { the contribution will continue for next } 10 \text { years. }\end{array}$ \\
\hline 6 & Art \& culture & As a promising to the society, Southeast Bank helps to nurture art and culture of Bangladesh. \\
\hline 7 & Others & $\begin{array}{l}\text { Donation to Common Wealth journalist Association. Donation to Dhaka University. Donate to } \\
\text { Bangladesh Hockey Federation. Donate to the Institute of Bankers, Bangladesh. Financial } \\
\text { Assistance to Family of late poet Shamsur Rahman. }\end{array}$ \\
\hline
\end{tabular}




\section{Findings \& Recommendations}

The SoCBs and PCBs have involvement in CSR activities. And from those here have some findings:

- Participation of the banks in different areas of CSR activities is limited.

- The SoCBs and PCBs contribute mainly in education, health, and care disaster relief and arts and culture.

- The environment and sports get little concern of CSR.

- Expansion of technology still does not provide good concern to all SoCBs and PCBs.

- The status of invention function is also not favorable.

\section{Recommendations}

- The highest emphasis should be given to the education sector. Because, it is the backbone of a nation.

- Special initiatives should be taken for women empowerment.

- Bangladesh is doing well in sports in recent times. It needs to boost more through CSR activities.

- Environment is a growing concern all over the world. So, it is needed to give special concern.

- Expansion of technology needed provides good concern.

- Invention function is also needed to provide favorable care.

- Both banks invest in industries that produce social, cultural, or religious development.

- Banks can invest in green business.

- Ensuring those investments that are harmful for the banks as well as their clients and environment.

- Bank can patronize green IT sectors.

- Establishing a fund to support the victim of natural disaster.

- Needed to effort pros and cons of CRS act in Bangladesh.

\section{Conclusion}

Bangladesh, as a third world state, has lots of complications. The government frequently discovers themselves helpless while it approaches to the solution of these difficulties. As corporate possessors of this state are measured as a part of the wealthy unit of the society and they can donate more profoundly in the direction of the improvement of the society. CSR has become a standard of generally legitimate corporate effort and the acceptance of its gradual rises. By CSR events, business groups can do societal and charitable events for fostering justifiable and supportable social progress. After the study, it is crystally clear that banks are conscious about CSR activities and their donations are growing over the year. However, the involvement is not satisfactory for a state like Bangladesh, where around a lot of CSR parts are essential to more charities from the business segments. Government and Bangladesh Bank should shape a more appropriate standard to increase the CSR support by SoCBs and PCBs. Though SoCBs and PCBs are still lagging behind in CSR contribution, yet if all the SoCBs and PCBs give appropriate consideration to this vital issue and add to CSR events, it will play a noteworthy role in moderating of social responsibilities.

\section{References}

Agrani Bank Limited. (2014). Annual Report 2013. Dhaka: ABL.

Agrani Bank Limited. (2015). Annual Report 2014. Dhaka: ABL.

Agrani Bank Limited. (2016). Annual Report 2015. Dhaka: ABL.

Ahmed, I. (2012). The Bangladesh economy: Prospects for the future. The Financial Express. Retrieved from: http://www.thefinancialexpress-bd.com/old/more.php?news_id=131987\&date=2012-06-06 
Alimullah, M. (2006). Dynamics of corporate social responsibility—Bangladesh context. Journal of AIUB Bangladesh, 3(1), 13-32.

Azim, M., Ahmed, E., \& D’Netto, B. (2011). Corporate social disclosure in Bangladesh: A study of the financial sector. International Review of Business Research Papers, 7(2).

BRAC Bank. (2016). Annual Report 2015. Dhaka: BBL.

Bangladesh Bank. (2015). We shall overcome: Review of CSR activities of Bangladesh Bank, commercial banks \& financial institutions-2014. Dhaka: Bangladesh Bank.

Carroll, A. B. (1991). The pyramid of corporate social responsibility: Toward the moral management of organizationalstakeholders. Business Horizons, 34, 39-48.

Crane, A., \& Matten, D. (2007). Corporate social responsibility as a field of scholarship. Corporate Social Responsibility, 1. Andrew Crane, Dirk Matten, London: Sage.

Islam, S. (2014). Banglapedia: National encyclopedia of Bangladesh. Dhaka: Asiatic Society of Bangladesh.

Janata Bank Limited. (2014). Annual Report 2013. Dhaka: JBL.

Janata Bank Limited. (2015). Annual Report 2014. Dhaka: JBL.

Janata Bank Limited. (2016). Annual Report 2015. Dhaka: JBL.

Janata Bank Limited. (n.d.).Welcome to Janata Bank Limited Bangladesh. Retrieved on 12 November, 2015, from http://www.janatabank-bd.com/

Janata Bank Limited. (n.d.). In wikipedia. Retrieved on 12 November, 2015, from https://en.wikipedia.org/wiki/Janata_Bank

Khan, H. U. Z., Azizul Islam, M., Kayeser Fatima, J., \& Ahmed, K. (2011). Corporate sustainability reporting of major Commercial banks in line with GRI: Bangladesh evidence. Social Responsibility Journal, 7(3), 347 -362.

Mahbuba, S., \& Farzana, N. (2013). Corporate social responsibility and profitability: A case study on Dutch Bangla Bank Ltd. International Journal of Business and Social Research, 3(4), 139-145.

Sonali Bank Limited. (2013). Annual Report 2013. Dhaka: SBL.

Rupali Bank Limited. (2014). Annual Report 2013. Dhaka: RBL.

Sonali Bank Limited. (2014). Annual Report 2014. Dhaka: SBL.

Rupali Bank Limited. (2015). Annual Report 2014. Dhaka: RBL.

Sonali Bank Limited. (2015). Annual Report 2015. Dhaka: SBL.

Rupali Bank Limited. (2016). Annual Report 2015. Dhaka: RBL.

Rupali Bank Limited. (n.d.). In wikipedia. Retrieved on 12 November, 2015, from https://en.wikipedia.org/wiki/Rupali_Bank

Masud A. K. (2011) CSR practices of private commercial banks in Bangladesh: A comparative study. MPR A paper no. 35496 online at http://mpra.ub.uni-muenchen.de/35496

Safety \& Rights Society. (2014). Corporate social responsibility in Bangladesh: Practice and perpetuity. Safety \& Rights Society: Dhaka.

Quazi, A., Rahman, Z., \& Keating, B. (2007). A developing country perspective of corporate social responsibility: A test case of Bangladesh.

The City Bank. (2016). Annual Report 2015. Dhaka: CBL.

Standard Bank. (2016). Annual Report 2015. Dhaka: SBL.

Southeast Bank. (2016). Annual Report 2015. Dhaka: SEBL.

Yoon, Y., Gürhan-Canli, Z., \& Schwarz, N. (2006).The effect of corporate social responsibility (CSR) activities on companies with bad reputations. Journal of Consumer Psychology, 16(4), 377-390. 